\title{
The New Way:
}

\section{How to Achieve Indonesia Higher Economic Growth in 2020}

\author{
Rizal Ramli \\ A Coordinating Minister for Maritime Affairs under President Joko Widodo administration as well as \\ Coordinating Minister for Economic Affairs and Minister of Finance under the President Abdurrahman \\ Wahid administration
}

\begin{abstract}
Rizal Ramli, a prominent national figure, senior technocrat and economist, argues that the government must reverse the logic built so far: Indonesia must first increase its economic growth to above $7 \%$, then investment will surely come again. This paper is a his view of the economic conditions of the Jokowi era and how to rebuild Indonesia's economy going forward to rise from an alarming slump So far, he argues, deindustrialization has accelerated in the Joko Widodo era. The setback is marked by growth in the manufacturing industry sector until the third quarter of 2018 was $4.3 \%$ slower than the growth in the same period in 2017 at 4.8\% and the processing industry growth rate is $4.3 \%$, lower than the economic growth rate of $5 \%$.
\end{abstract}

Keywords

Indonesia economy, Jokow; SBY; setback industry

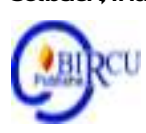

\section{Introduction}

At the end of 2017, I stated that up until 2019 Indonesia economic growth will only be around 5\%. This is not strange, because our macroeconomic policies are super conservative: we listen to the World Bank and its main program in tightening or austerity.

This austerity program has in fact failed in Latin America. In Greece, it failed up to 3 times. Taxes were pursued and budgets were cut only in order to leave money to pay creditors. So, the certainty is only to pay creditors. Stagnation of the economy, plummeting purchasing power, dissatisfied people - all that is irrelevant for them. What matters is that creditors must be the number one priority.

That's their goal, the one that gets praised by foreigners. They think it's good that the budget is cut, as there are installments to pay and only the interest payment is announced. However, if you also consider the principal payment of debt and debt interest in the 2020 State Budget, the total used for paying down debt would be up to IDR 646 trillion. Therefore, the key priority of our budget is to pay off debt, the second education, and the third infrastructure. So far, it seems as if the number one is infrastructure.

The decline in Indonesia's economic growth rate can be seen from the Bank Indonesia (BI) report, which states that current account deficit (CAD) is USD 8.4 billion or $3.04 \%$ of our Gross Domestic Product (GDP) in the second quarter of 2019.

The current account continues to decline, to up to USD 8 billion more than the rise in GDP. This is very dangerous. Why? Because all other countries' analysts see more than this. 
Konfrontasi Journal: Culture, Economy and Social Changes, 7 (1) March 2020, 1-7

ISSN: 1410-881X (Print), 2716-2095 (Online)

Rizal Ramli: The New Way: How to Achieve Indonesia Higher Economic Growth in 2020

DOI: https://doi.org/10.33258/konfrontasi2.v7i1.101

http://www.konfrontasi.net/index.php/konfrontasi2

The question is, are there other ways or alternative ways to boost Indonesia's economic growth? The answer is yes. And it's not just a fairy tale. As Einstein said, "Don't expect different results if you still use the same method."

If I say we can easily raise the Indonesian economy from 5\% to $6 \%$ in less than a year, people will become optimistic again, but it is not permissible to join the World Bank and its Austerity Program because the economy has weakened; it has increasingly tightened. It is actually very simple. In developed countries, a weakening economy is loosened, given a boost, so that it rises faster. Only when the economy has recovered will it be taxed. But the World Bank does this for the benefit of creditors. What matter is that we have money to pay debts, so we implement austerity.

16 years ago, I became the Coordinating Minister of Economy during Gus Dur's presidency. When I arrived, the economy was $-3 \%$. I was appointed in October, then in January, I made a call and said that I wanted to go to New York to be ranked. Usually, ratings are done in August, but I went there in January. I usually go out of the box or make a breakthrough. I also didn't want our economy to be rated by Singaporean analysts, who already knew Indonesia's negative points. The boss in New York only has a general knowledge of our situation. Finally, I went there in January with our team.

We were tested from 9 am to $5 \mathrm{pm}$. I had two choices. We offer the Austerity Program, I wanted to cut this budget and that; the rating agent would be very happy because it means there is money for creditors. Our rating must have been raised today by budget cuts in the same way. I didn't want that; that's too easy and convenient if I just cut the budget. We offered a growth strategy on how to revive the economy quickly; we promised within 2 years we will raise our economy from $-3 \%$ to $3 \%$ or an increase of $6 \%$.

How did we do that? One of the ways we did this was through real estate. The real estate sector was all stuck at the Indonesian Bank Restructuring Agency (IBRA), they could not move. After returning home, I cut the interest rates that were too high. The "head of the dragon" lies in real estate. If real estate falls, other sectors will follow suit. Then we will boost exports. They believed in my scheme and I went home. Within the month, Indonesia rose one rank without austerity. It turned out that in the 21 months of the Gus Dur government, we managed to raise the economy from $-3 \%$ to $4.5 \%$ or up $7.5 \%$. Logically, if the economy grows, debt increases. We did not do that. We did it out of the box, debt was exchanged for a lower debt interest rate. We paid our debt to Kuwait all at once in order to get a cheaper, i.e. lower interest, debt.

The Minister of Finance of Kuwait was very happy. He said, "I am no longer criticized because Indonesia's debts have not been settled for decades. I am not criticized anymore in the Kuwaiti Parliament. I want to give you a present, what do you want?" I said "I used to stay in Bandung for a long time, and every time I go to Bandung, the traffic gets stuck. Please build the Pasopati Flyover." So now we got that for free. Therefore, there are many ways to innovate when you want to pay off debts. Then we did that in the CGI (Consultative Group of Indonesia) negotiations in Tokyo, I got a USD 500 million grant, the highest in the history of Indonesia. We also performed a debt-to-nature swap with Germany. As a result, the Gus Dur government was the only government that reduced debt by USD 4.15 billion. All other governments have always added debt. 


\section{Review of Literature}

Our Gini Index was the lowest in history. We managed to maintain stable food production without imports. It's possible for us not to import rice. The Minister of Industry and Trade at that time, Mr. Luhut Pandjaitan, said, "Let us boost exports." Mr. Luhut was aggressive and our exports shot up twice. Next, we needed to ensure that people's purchasing power was strengthened, prices stayed stable, purchasing power did not go down. We increased civil servant salaries by $125 \%$ in 21 months; we did this twice. The condition is that we had to leave the conservative macro policy tightening program.

For me, I'm sorry for saying this, raising from $5 \%$ to $6 \%$ is not difficult. I say it to Mr. Jokowi. First, the budget is used for the outer islands only. Therefore, it is Indonesia-centered as Mr. Jokowi wants, not Java-centered. In Java, we use non-budget financing. We use BOT. What is "BOT"? It is "Build Operate Transfer", asset security and asset revaluation. When I was the Coordinating Minister, I suggested to the President that we re-evaluate assets, but only if I and Mr. Jokowi agreed. We only managed to persuade 16 State-Owned Enterprises (SOEs) to go along with our scheme. However, as a result, their assets increased by IDR 800 trillion; with tax at $4 \%$ we earned IDR 32 trillion.

I want all SOEs to reevaluate their assets. We will be able to increase SOE assets to IDR 2,500 trillion, gaining IDR 100 trillion in taxes. This is bigger than tax amnesty earnings. SOEs have the leverage to finance projects throughout Sumatra. This is not a fairy tale because I did it 16 years ago. PLN almost went bankrupt, with minus of IDR 9 trillion in capital, and only IDR 50 trillion in assets. The Board of Directors asked for an injection of the State Budget, I said "No way, please reevaluate your assets instead." It turns out that PLN's assets rose from IDR 50 trillion to IDR 200 trillion. I increased its capital from minus IDR 9 trillion and was almost bankrupt at IDR 104 trillion, while the rest of the money became working capital. I saved PLN 16 years ago. Otherwise, PLN would have already gone bankrupt.

If we reevaluate assets, we have money to finance this, but it is not a country that is in debt. The financing will come from SOE or securing of assets. If Mr. Jokowi agreed with this securing, we do not sell assets, we do not sell the SOEs, but we will accept the future investment in the next 10 years at a lower cost than bonds. Other ministers are busy selling this and that, even though Mr. Jokowi wants the government to secure assets.

Second, how do we get our credit to grow above $15 \%-17 \%$. These days, credit only grows by $10 \%$. If credit growth is $17 \%$, then the economy can grow by $6.5 \%$.

Third, all foreign imports to Indonesia are doubly expensive. Sugar prices in Indonesia are twice as expensive as those in Australia, Bangkok, and Malaysia. Meat prices are also twice as expensive. This is because they are controlled by quota-holding cartels. I suggested in the Cabinet that we change the system, anyone may import. Let's just charge a $25 \%$ rate. Food prices automatically fell by $75 \%$. The people are very happy. Middle-class housewives used to shop IDR 200,000.00 every day now pay only IDR $150,000.00$ because meat prices are $75 \%$ cheaper; tofu, tempeh were cheaper. So we indirectly give IDR 50,000.00 a day to these ladies, multiplied by 30 days, making it a total of IDR 1.5 million each. We gave IDR 60 million to these middle-class families, which inevitably creates buying power.

Fourth, do not make incremental, gradual policy packages because our problems are complicated already. If we do it slowly, we might drown. For example, what is the use of deregulation? That is good for foreign trust. Therefore, we need to dare to implement breakthrough policies. 16 years ago, when I became Coordinating Minister, airplane passenger numbers dropped by $60 \%$ because of the 1998 crisis; this was still felt in 2000 . I called the airlines - they were all SOEs at the time, Garuda, Mandala, Merpati "Can you 
lower the rates?" They said "Yes, but we don't do it because the market is an oligopoly." Finally, we got upset, we issued licenses to 6 new airlines. There were Lion Air, Sriwijaya Air, and others. They only needed one leased airplane as capital. Thanks to their existence, there was competition. Passenger costs per $\mathrm{km}$ dropped by $60 \%$. People who had never been on a plane were now flying. Total passengers compared to that in 2000 is now 7 times greater so that it is like a bus terminal. The other airlines became giants, Lion Air and Garuda. That is an example of changing Indonesia without money. Breakthrough first.

We can generate high quality and ecological economic growth at an average of $8 \%$ with the following 7 strategic steps:

Build 1 million Subsidized Housing units a year (3 times the achievements of the Jokowi Government), which will create 3 million direct and indirect jobs per year.

The backlog now is 15 million housing units. Jokowi is now only able to build 300,000 units/year, while he should be able to build 1 million units/year like Roosevelt and Lee Kwan Yew did. Here's how:

1. a. State land must be used. For the people of Java, 2-room apartments are built, while people outside Java were given a $50 \mathrm{~m} 2$ core house with a land area of $200 \mathrm{~m} 2$.

b. Financing should be lowered from $7 \%$ to $3 \%$, so the price of a house/apartment could be set at around IDR 150 million. With a $3 \%$ loan interest rate for 10 years, the value will increase by $38 \%$ to around IDR 207 million. Divided over 10 years, monthly credit installments will be IDR 1.7 million.

This construction of public housing will significantly affect job creation. Around 3 million people will get jobs, directly or indirectly, while GDP growth will increase by $1.5 \%$.

2. Increase people's purchasing power by lowering the price of the basic electricity tariff ( 450 VA and $900 \mathrm{VA}$ ) and reducing the price of imported food.

3. Double farmers' income within 5 years and build 1 million hectares of rice fields, 1 million hectares of corn plantations, and 0.5 million hectares of sugarcane plantation. Provide as much fertilizer as possible to meet the needs of farmers by reducing leakage of subsidized fertilizer to large plantations. The provision of organic fertilizer will also be increased to maintain soil quality. Increase the production of milk, meat, and chicken to revive the people's livestock industry.

We must build 1 million hectares of rice fields in Southeast Sulawesi, Central Sulawesi, and South Sulawesi, with mechanization. We need to do this in parts of Sumatra and Bangka as well, because the lands are quite flat. This will increase rice production by at least 5 million tons.

Establish a 1/2 million Ha sugarcane plantation. Establish 1 million Ha of corn plantations, which can be integrated with the 5 million Ha Sustainable Reforestation plan.

What's important is: Who will be the farmers? The farmers must be given benefits and profits, like those in South Korea, Japan, and Taiwan. A pricing policy must be set so that farmers can get an additional 10\% profit and double their growth rate in 7 years. Only then will young people want to become farmers because they will have enough purchasing power.

4. Increase fishermen's income by giving fishing boat permits to catch fish in lucrative areas in Eastern Indonesia and Natuna. Fishing boats and fishing gear suitable for the fishermen's needs will be provided so that the people's boat making industry will also develop. Fishermen villages will also be developed according to eco-tourism principles in order to increase fishermen's income.

5. Accelerate the transformation of fossil energy into alternative energy (sun, wind, geothermal, water, and garbage). The development of energy in remote areas and small islands (less than 20MW); it could be carried out by the local people and government. 
If you expect additional oil production alone it will not be possible. So that which must be relied on is gas, geothermal, sun, and other alternative energy.

The current problem is that PLN, the State owned Electricity Company, wants to continue using coal as raw material at a cost of USD $0.055 / \mathrm{kWh}$, while other alternative energy sources are priced at USD 0.12-0.20. So in principle, there must be a shift from fossil energy to alternative energy. It also fulfills the Paris COP21 agreement (2030 target: global warming at $<2 \mathrm{C}$ ).

Today PLN buys coal at USD $0.055 / \mathrm{kWh}$, transmission costs are USD $0.015 / \mathrm{kWh}$, with PLN's profit at USD $0.02 / \mathrm{kWh}$. PLN should be able to sell electricity at USD 0.09/kWh, but it sells to industries at USD 0.08-0.09 and to the consumers at USD 0.012/ $\mathrm{kWh}$. There's a leak here because industrial electricity is leaking into real estate.

6. Develop a national industry that produces environmentally friendly, energy-efficient, and economical electric cars and bicycles.

7. Develop national industries that produce biomass energy based on sustainable reforestation

\section{Discussion}

\subsection{Social Welfare}

Poverty reduction in the Joko- wi era has been very slow due to stagnant economic growth, at $5 \%$ over the past 4 years. The cur $\neg$ rent poverty reduction rate is the lowest yet, only raising 520,000 people per year. Compare that with the SBY era when pover $\neg$ ty reduction rate was 840,000 people a year (down $5.4 \%$ in 10 years), the Megawati era at 570,000 people per year (down $1.75 \%$ in 3 years), the Habibie era by 1.53 million people per year (down $0.77 \%$ in one year). The fastest rate of poverty re $\neg$ duction was in the Gus Dur era at 5.05 million people per year (down $5.02 \%$ in 2 years).

With such high and quali $\neg$ ty economic growth, the rate of unemployment reduction and poverty reduction will certainly be much faster (at least 1 million people per year) because there will be a lot of jobs for the people (at least 15 million new jobs in 5 years). Besides, workers' wages will definitely rise.

Provide clean water for the Indonesian people, because the continuity of human life is very dependent on water. All water companies, PDAMs, will be re $\neg$ structured and revitalized in order to be able to expand and the quality of clean water can im $\neg$ prove. A water production system with better quality suitable for drinking will be built in 10 major cities in Indonesia.

$90 \%$ of the existing 350 PDAMs are losing money due to corruption and low distribution rates. We can fix that by restruc $\neg$ turing and reducing corruption. We need to build potable water facilities in 10 big cities. It makes no sense that the price of drink-ing water is almost half the price of premium gasoline.

\subsection{Finance}

Access to bank credit for mil $\neg$ lions of small and medium-sized businesses owned by the people must be increased. So far $83 \%$ of bank credit only goes to a few hundred large businesses and SOEs, while only 17\% (including KUR) flows to millions of small and medium-sized businesses which absorb the largest part of the workforce. The Indonesian government must change this uneven credit structure gradᄀually in order to revive small and medium enterprises. Large businesses and SOEs must be encouraged to look for other sources of funding, such as from the issuance of bonds or the sale of shares. 
The imposition of a final tax of $0.5 \%$ from small and mediᄀum-sized businesses is still very burdensome, although Jokowi is often proud of it as the form of his partiality towards these businesses. This rate is still heavy because of it is an entire one quarter (1/4) of the average Net Profit Margin (NPM) of small people's businesses at only 2\%. The Indonesian government will remove the tax for small and me $\neg$ dium businesses up to a profit limit of IDR 2 billion.

\subsection{Industry}

Deindustrialization has ac $\neg$ celerated in the Jokowi era: 1) Growth in the manufacturing industry sector until the third quarter of 2018 was $4.3 \%$ slow 7 er than the growth in the same period in 2017 at $4.8 \%$ (Minis $\neg$ try of Industry Data); and 2) The processing industry growth rate is $4.3 \%$, lower than the econom $\neg$ ic growth rate of $5 \%$. We need to double the growth of the proncessing industry from its current position to around $8 \%$ in 2020 - 2024.

\subsection{Investment}

Jokowi's method of pleading to the international world for investment to come has not been effective. In the third quarter of 2018, actual investment decreased (-) $1.6 \%$ from to that of the same period in 2017 (BKPM data). Investors do not choose to come to Indonesia because our economic growth is only $5 \%$. They ultimately prefer to come to our neighboring countries that have higher economic growth, such as Vietnam $(7.1 \%)$, India $(7.1 \%)$, or the Philippines (6.2\%).

\section{Conclusion}

In the Constitution 1945 it is quite clear that the economic system that Indonesia must adhere to. It is just that we are consistent in elaborating the Constitution in laws and implementing regulations, from government regulations to local regulations. But, what is happening now is that we have already been crushed by the neoliberal economy. To realign Indonesia's politics and economy which is misdirected, we must have an assessment of Indonesia's socio-political and economic situation.

Based on the descriptions above, the government must reverse the logic built so far: Indonesia must first increase its economic growth to above $7 \%$, then investment will surely come again.

\section{References}

Alice Calaprice, Ed., The Ultimate Quotable Einstein, Section: Misattributed to Einstein, Quote Page 474, Princeton University Press, Princeton, New Jersey, 2010

Umesh Bhagchandan, 3 Things You May Not Know About Dr Rizal Ramli

http://indonesiatatler.com/fashion-beauty/fashion/3-things-you-may-not-know-about-dr-rizalramli

Rizal Ramli, Role of Forestry Sector in Economy of Indonesia, [Jakarta]: Wahana Lingkungan Hidup Indonesia, 1993 [i.e. 1994]

Bank Indonesia (BI) report, 2019, https://www.bi.go.id/en/publikasi/laporantahunan/bi/Default.aspx, accessed April 20, 2019

Rizal Ramli, Prospect for the Economy and Democracy in Indonesia, Post Yudhoyono Indonesia and Asian Power, paper, New York: The United Nation's Second Advisory Panel Meeting bulan Juni 2012, 
Rizal Ramli, Indonesia Strategic Economic \& Political Outlook and Asian Powers, Indonesia's Economic Outlook and Asian Economic Integration, Indonesian Democracy at The Cross Road, paper, New York: The United Nation's Second Advisory Panel Meeting bulan Juni 2012,

Herdi Sahrasad, Editor, Rizal Ramli: Blok Perubahan, nyala lilin dalam Kegelapan, Pusat Studi Islam dan Kenegaraan, Universitas Paramadina, 2009

https://www.bkpm.go.id/images/uploads/file_siaran_pers/Narasi_Indonesia_TW_IV__2017.pdf, accessed January 12,2019. 